\title{
The Effect of Scientific Approach on Students’ English Achievement for Junior High School Level in Riau Province, Indonesia
}

\author{
Abdullah Hasan ${ }^{*}$ \\ State Islamic University of Sultan Syarif Kasim Riau, Indonesia \\ *Corresponding author: abd_hasanuin@yahoo.com
}

\begin{abstract}
The main goal of this study is to determine the effects of the scientific approach through Information Communication Technology (ICT) of curriculum 2013 on students' English achievement. The research utilized a quasi-experimental study of the pretest - post-test of non-equivalent group design. The participants of the study comprised 160 students and three intact teachers from three Junior High schools in Kampar regency of Riau province. The scientific approach with three aspects of attitude, skill and knowledge competencies through ICT were used for the treatment of the study. Data were collected using pre-test and post-test to measure the students' English achievement before and after conducting treatments for 12 meetings; then, an observation sheet was administered to investigate the implementation of the scientific approach done by the teachers. Two research questions and four hypotheses were posted in this research. Teaching and learning process of scientific approach through ICT with the strength of attitude, skill and knowledge made the students became more active, creative, effective and joyful learning to achieve the learning objectives. It also made the class became student centered instruction. The findings showed that there were significant effects of the scientific approach through ICT of curriculum 2013 on students' English achievement.
\end{abstract}

Keywords: the scientific approach, ICT, curriculum 2013, English achievement

Cite This Article: Abdullah Hasan, "Template for Preparing an Article." American Journal of Educational Research, vol. 6, no. 2 (2018): 123-128. doi: 10.12691/education-6-2-5.

\section{Introduction}

No one will question the fact that English has achieved some sorts of global status. Three linked events created the opportunity for English to spread worldwide and fulfill social and economic functions in the lives of people from many nations [1]. Then, many regard the spread of English around the world as the beneficial result of a natural process, in which English is benignly chosen as a trade lingo of choice because as a language it is somehow neutral in its social, political and economic entailment. In reality, nothing could be further from the truth.

English plays a very important role in the major aspects of life in this global era. It is the most widely spoken language in the world so that English today is fast becoming a lingua franca of international trade and commerce. With the challenges posed by globalization and technological advances, Information and Communication Technology (ICT) has become the most crucial one in gathering scientific information available on electronic media. It is also observed that most of the books of science and technology are written in English.

In fact, more learners get problems in learning English. In Indonesia, for example, Abdullah Hasan \& Rohaty in Suwarsih ([2]: 4) stated that senior high school graduates who have learned English for six years, with almost
900 hours of school teaching, were unable to use English for communicative purposes. This phenomenon can also be observed among university graduates and even among faculty members. The teaching of English has so far not helped teachers and students achieve their declared goals despite many efforts made to improve its quality.

That is also one of the reasons why English curriculum and approach keep on changing from time to time. The change of curriculum 2013 gives challenges to headmasters, teachers, students and administration staffs. All of them should be able to master information technology. The main problem is human resources that involve to run curriculum 2013. What is going on to teachers and administration staffs have the weaknesses and hindrances on how to run or operate information technology even-though various efforts have been done such as: the government and school concern have tried to run workshop training for ICT. Another problem dealing with facilities, in majority, all school levels have problems with electricity and Wi-Fi. So, the government should give the first priority how to fulfill these facilities especially in remote areas.

The basic change of curriculum 2013 focuses more challenges to both teachers and students to master information technology. It is hoped the students able to filter the negative effects of the globalization era when they access information from internet. Having attitude as one of the aspects of scientific approach will lead the 
students to have the good behavior or characteristics. It is in accordance with the claim of 1945 constitution and national education system of Indonesia.

The scientific approach includes three competencies of attitude, skill and knowledge. Learning outcomes are able to produce students become productive, creative, innovative and effective through the integration of the strength of attitude, skill and knowledge. The aspect of attitude makes the students able to transform the teaching materials in order to lead them "why to know"; and the aspect of skill makes the students able to transform the teaching materials the students able "how to know"; the aspect of knowledge makes the students able to transform the teaching materials able "what to know"; and the last result is to improve and to make the students to have balance between soft- skill and hard skill which covers the aspects of attitude, skill and knowledge competencies [3].

The scientific approach focuses on the dimension of modern pedagogy in teaching and learning process. The communicative approach places emphasis on developing the communicative competence, viewed as "the overall underlying knowledge and ability for language use which the speaker-listener possesses" [4]. Furthermore, it also integrates information communication and technology (ICT) to all subject matters of syllabuses. The effect of this integration, subject matter of Information Technology has been dismissed at junior high school level and it is integrated to every subject matter. Five steps consist of observing, questioning, associating, experimenting and networking are administered in teaching and learning process of scientific approach of every subject matter. The approach is conducted on student centered instruction, and the roles of a teacher in teaching and learning process are as controller, organizer, assessor, prompter, participant, resource, tutor and observer ([5]: 56-62). The students are arranged into pairs and groups. Furthermore, Harmer ([5]: 120) also states a key consideration when putting students in pair or groups is to make sure that we put friends with friends, rather than risking the possibility of people working with others whom they find difficult or unpleasant. The use of student -centered activities allows teacher to spend more of their time diagnosing and correcting student problems, consulting with individual students, and teaching one-on-one and in a small group [6]. Intention is the collaborative exchange of thoughts, feelings and ideas between two or more people, resulting in a reciprocal effect to interact on each other [7].

\section{Objectives and Research Questions}

The main objective of this study was to explore the effects of the scientific approach through ICT towards the students' English achievement and to find out the differences among three categories of Junior High School levels in Kampar regency. The specific objectives were as follows:

- To determine the effects of the scientific approach through ICT towards the students' English achievement at junior high school level in Kampar regency.

- To determine the differences among three school categories on the students' English achievement using the scientific approach through ICT.
Two research questions are formulated as follows:

- Is there any significant effect of the scientific approach through ICT towards the students English achievement?

- Are there any significant differences among three school categories on the students' English achievement using the scientific approach through ICT?

\section{Materials and Methods}

The research design was a quasi-experimental study of the pre-test-post-test design, and three research questions were posed to explore the effects of the scientific approach through ICT towards the students English achievement. Cohen, L. Manion, L \& Morrison, K [8] state that it is one of the most commonly used quasi-experimental designs in educational research.

A quasi-experimental design was selected for this study because of the following factors: (a) the administrative constraints by the selected school that does not allow for the random selection (b) based on the real condition, it is not realistic to conduct the study in true experimental design due to the complexity of human behavior and language behavior, and the difficulty of defining various variables involved in language learning [9]; quasi-experimental design can reflect what happens in the real life settings without any disruption in the educational set-up; therefore, this eliminates 'artificially' existing in true experiments and also shows that ecological validity of such designs is strong [10,11]; (d) the results of quasi-experimental research, as Bryman [10] argues, is still 'compelling' and particularly prominent in evaluation research studies; and (e) the use of intact classes in quasi-experimental designs could reduce the threat of Hawthorne effect that can often result when subjects are randomly selected and assigned to conditions for the cooperative lesson periods [12].

The participants of the study were 160 students from three selected junior high schools in Kampar regency of Riau province. The second set of subjects consisted of three English teachers who have volunteered to teach the experimental groups using the scientific approach through ICT toward students' English achievement. Cluster sampling was used that randomly selected groups, not individuals. All members of selected groups had similar characteristics. A good sample is one that is representative of the population from which it is selected, and cluster sampling is the best single way to obtain a representative sample [13]. The data were obtained by using a pre-test and a post-test. The pre-test was used to determine the basic English mastery before the treatment. The post-test was administered to determine the students' English achievement. This research was conducted for 12 meetings or 24 class-hours within three months. The implementation of each meeting used the scientific approach through ICT which provided with a lesson plan and a procedure. The procedure was divided into three steps; pre-activities consisted of opening the lesson, motivating strategy and apperception; whilst-activities covered observing, questioning, associating, experimenting and networking or communicating; and then, ended with post-activities implemented reflex-ion, conclusion and closure. In the whilst-activities, especially, the teachers used ICT like multimedia teaching aids to 
implement the five steps that made the students became more active, creative, effective and joyful learning to achieve the objectives of the lesson. Besides, teaching and learning process became a student-centered instruction with modern pedagogy through the integration of the strength of attitude, skill and knowledge.

\section{Results}

The hypotheses posed in this study were analyzed by using an independent sample t-test, a paired sample t-test and ANCOVA of inferential statistics based on participants' responses of pretest, post-test and questionnaire.

Ho1: There is no significant difference of the students' English achievement pre-test mean scores before treatment between experimental and control groups

Pallant [14] states that if the significance value is greater than 0.05 , this indicates that there is no violation of the assumption of equality of variance and that equal variances are assumed for the variable concerned. An independent sample t-test was conducted to determine any significant difference between pretest mastery mean scores of experimental and control groups. The result of pre-test mean scores for State Junior High School number one (SMPN 1) Bangkinang is presented at the following table:

Table 1. Pretest results between experimental and control groups of SMPN 1 Bangkinang.

\begin{tabular}{ccccccc}
\hline Group & N & Mean & SD & DF & T & $\boldsymbol{P}$ \\
\hline Experiment & 29 & 56.34 & 11.564 & 56 & -656 & 0.515 \\
control & 29 & 58.27 & 10.85 & & & \\
\hline
\end{tabular}

$\mathrm{p}>0.05$.

Based on Independent sample t-test analysis for pretest mastery of experimental and control groups on Table 1 above, it shows no significant difference was found at pretest English mastery. The result showed that the mean scores did not differ much between both groups. It could be determined that the subjects in both groups were equivalent. Mean for the experimental group was 56.54 and $\mathrm{SD}=11.564$ and the mean for the control group $=58.27$ and $\mathrm{SD}=10.85$.

Table 2. Pretest results between experimental and control groups of MTs As_Salam

\begin{tabular}{ccccccc}
\hline Group & N & Mean & SD & DF & T & $\boldsymbol{P}$ \\
\hline Experiment & 21 & 41.90 & 9.1807 & 40 & -093 & 0.926 \\
control & 21 & 41.61 & 10.072 & & & \\
\hline
\end{tabular}

$\mathrm{p}>0.05$.

Based on Independent sample t-test analysis for pretest mastery of experimental and control groups on Table 2 above, it shows no significance was found at pretest English mastery. The result showed that the mean scores did not differ much between both groups. It could be determined that the subjects in both groups were equivalent mean for experimental group was 41.90 and
$\mathrm{SD}=9.1807$ and the mean for control group $=41.61$ and $\mathrm{SD}=10.072$

Table 3. Pretest results between experimental and control groups of SMPN 1 Kampar Timur

\begin{tabular}{ccccccc}
\hline Group & N & Mean & SD & DF & T & $\boldsymbol{P}$ \\
\hline Experiment & 28 & 42.14 & 10.124 & 54 & -371 & 0.712 \\
control & 28 & 43.14 & 10.072 & & & \\
\hline
\end{tabular}

$\mathrm{p}>0.05$.

Based on Independent sample t-test analysis for pretest mastery of experimental and control groups on Table 3 above, it shows no significance was found at pretest English mastery. The result showed that the mean scores did not differ much between both groups. It could be determined that the subjects in both groups were equivalent mean for experimental group was 42.14 and $\mathrm{SD}=10.124$ and the mean for control group $=43.14$ and $\mathrm{SD}=10.072$.

Ho2: There is no significant difference of the students' English achievement post-test mean scores after treatment between experimental groups and control groups.

An independent sample t-test was conducted to determine any significant difference on post-test mastery mean scores between experimental and control groups. The findings are shown at the following table:

Table 4. Posttest results between experimental and control groups of SMPN 1 Bangkinang

\begin{tabular}{ccccccc}
\hline Group & N & Mean & SD & DF & T & $\boldsymbol{P}$ \\
\hline Experiment & 29 & 78.86 & 5.370 & 56 & 6.933 & 0.000 \\
control & 29 & 68.27 & 6.227 & & & \\
\hline
\end{tabular}

$\mathrm{P}<0.05$.

Based on Independent sample t-test analysis for posttest achievement of experimental and control groups on Table 4 above, it shows significance difference was found at posttest English mastery. The result showed that the mean scores differed much between both groups. It could be determined that the subjects in both groups were not equivalent mean for experimental group was78.86 and SD $=5.370$ and the mean for control group $=68.27$ and $\mathrm{SD}=$ 6.227 .

Table 5. Posttest results between experimental and control groups of MTs As-Salam

\begin{tabular}{ccccccc}
\hline Group & N & Mean & SD & DF & T & $\boldsymbol{P}$ \\
\hline Experiment & 21 & 75.66 & 5.370 & 56 & 10.102 & 0.000 \\
control & 21 & 60.38 & 4.643 & & & \\
\hline
\end{tabular}

$\mathrm{P}<0.05$.

Based on Independent sample t-test analysis for posttest achievement of experimental and control groups on Table 5 above, it shows significance difference was found at posttest English mastery. The result showed that the mean scores differed much between both groups. It could be determined that the subjects in both groups were not equivalent mean for experimental group was75.66 and 
$\mathrm{SD}=5.370$ and the mean for control group $=60.38$ and $\mathrm{SD}=5.643$.

Table 6. Posttest results between experimental and control groups of SMPN 1 Kampar Timur

\begin{tabular}{ccccccc}
\hline Group & N & Mean & SD & DF & T & P \\
\hline Experiment & 21 & 68.142 & 7.715 & 54 & 6.827 & 0.000 \\
control & 21 & 58.071 & 5.291 & & & \\
\hline
\end{tabular}

$\mathrm{P}<0.05$.

Based on Independent sample t-test analysis for posttest achievement of experimental and control groups on Table 6 above, it shows significance difference was found at posttest English mastery. The result showed that the mean scores differed much between both groups. It could be determined that the subjects in both groups were not equivalent mean for experimental group was 68.142 and $\mathrm{SD}=7.725$ and the mean for control group $=58.271$ and $\mathrm{SD}=5.291$.

Ho3: There is no significant difference of the students' English achievement pre-test and post-test mean scores treatment in the experimental groups.

A paired sample t-test was conducted to determine any significant differences on post-test achievement mean scores in the experimental groups. The findings are shown at the following tables:

Table 7. The results of paired sample t-test between pretest and post test in the experimental group of SMPN 1 Bangkinang

\begin{tabular}{ccccccc}
\hline Group & $\mathbf{N}$ & Mean & SD & DF & T & $\boldsymbol{P}$ \\
\hline Pre-test & 29 & 56.34 & 11.564 & 28 & .13 .789 & 0.000 \\
Post-test & 29 & 78.56 & 5.370 & & & \\
\hline
\end{tabular}

$\mathrm{P}<0.05$.

The analysis based on Table 7 above using paired sample t-test shows that the mean score of post-test = 78.56 and SD $=5.370$ is higher than the mean score of pre-test $=56.34$ and SD 11.564, in which t-value .13 .789 with $\mathrm{P}=0.000$ or $P<0.05$. The result of data analysis is based on inferential statistics which has been identified after conducting the treatment for 12 meetings or 24 classhours by using the scientific approach through ICT and Islamic moral values can improve the students English achievement of SMPN 1 Bangkinang. In conclusion, Ho3 is rejected and Ha3 is accepted, so there is significant difference of mean scores on the learners' English achievement between pre-test and post-test scores after the treatment.

Table 8. The results of paired sample t-test between pretest and post test in the experimental group of MTs As-Salam

\begin{tabular}{ccccccc}
\hline Group & N & Mean & SD & DF & T & $\boldsymbol{P}$ \\
\hline Pre-test & 21 & 41.90 & 9.807 & 20 & .19 .992 & 0.000 \\
Post-test & 21 & 75.66 & 5.237 & & & \\
\hline
\end{tabular}

$\mathrm{P}<0.05$.

The analysis based on Table 7 above using paired sample t-test shows that the mean score of post-test = 75.66 and $\mathrm{SD}=5.237$ is higher than the mean score of pre-test $=41.90$ and $\mathrm{SD} 5.237$, in which t-value .19 .992 with $\mathrm{P}=0.000$ or $P<0.05$. The result of data analysis is based on inferential statistics which has been identified after conducting the treatment for 12 meetings or 24 classhours by using the scientific approach through ICT and Islamic moral values can improve the students English achievement of MTs As-Salam. In conclusion, Ho3 is rejected and $\mathrm{Ha} 3$ is accepted, so there is significant difference of mean scores on the learners' English achievement between pre-test and post-test scores after the treatment.

Table 9. The results of paired sample t-test between pretest and post test in the experimental group of SMPN 1 Kampar

\begin{tabular}{ccccccc}
\hline Group & $\mathbf{N}$ & Mean & SD & DF & T & $\boldsymbol{P}$ \\
\hline Pre-test & 28 & 42.14 & 10.124 & 27 & .12 .798 & 0.000 \\
Post-test & 28 & 68.14 & 7.715 & & & \\
\hline
\end{tabular}

$\mathrm{P}<0.05$.

The analysis based on Table 9 above using paired sample t-test shows that the mean score of post-test = 68.14 and SD $=7.715$ is higher than the mean score of pre-test $=42.14$ and SD 10.124, in which t-value .12 .798 with $\mathrm{P}=0.000$ or $P<0.05$. The result of data analysis is based on inferential statisticswhich has identified after conducting the treatment for 12 meetings or 24 class-hours by using the scientific approach through ICT and Islamic moral values can improve the students English achievement of SMPN 1 Kampar. In conclusion, Ho3 is rejected and Ha3 is accepted, so there is significant difference of mean scores on the learners' English achievement between pre-test and post-test scores after the treatment.

Ho4: There are no significant differences among three school categories on the students' English achievement using the scientific approach through ICT..

After hypothesis testing analyzed previously, the following Table 10 shows multiple comparison among three schools on the students' English achievement whether or not there are any significant differences among three school categories on the students' English achievement using the scientific approach through ICT.

Based on Table 10 of multiple comparison among three schools on the students' English achievement, SMPN 1 Bangkinang compared to MTs As-Salam with significant $0.240>0.05$ shows there is no significant difference on the student English achievement using the scientific approach through ICT. SMPN 1 Bangkinang compared to SMP N 1 Kampar with significant $0.000<0.05$ shows there is significant difference on the student English achievement using the scientific approach through ICT. Then, it can be concluded that SMPN1 Bangkinang and MTs As-Salam are similar, and SMPN 1 Kampar has significant difference compared to SMPN1 Bangkinang and MTs As-Salam.

Results of pretest among three school categories (Table 1-Table 3) which showed no significant differences on pretest mean scores between experimental and control groups. Meaning that the participants from three schools were homogeneous before being given the treatment. The results of posttest among three school categories (Table 4Table 6) which showed significant differences on posttest mean scores between experimental and control groups. Meaning that the participants from three schools obtained different achievement after the treatment. Then, the results 
of pre-test and posttest among three schools categories (Table 7 - Table 9) which showed significant differences on pre-test - post-test mean scores in the experimental groups. The last findings determined that there were significant effects of the scientific approach of curriculum 2013 through Information Technology on the students' English achievement at Junior High school level in Kampar regency.

Table 10. Multiple Comparison among three schools

\begin{tabular}{|c|c|c|c|c|}
\hline (I) Group & (J) Group & Mean Difference (I - J) & Std. Error & Sig. \\
\hline \multirow[t]{2}{*}{ SMPN 1 Bangkinang } & MTs As-Salam & 3.195 & 1.801 & .240 \\
\hline & SMPN 1 Kampar & $10.719 *$ & 1.665 & .000 \\
\hline \multirow[t]{2}{*}{ MTs As-Salam } & SMPN 1 Bangkinang & -3.195 & 1.801 & .240 \\
\hline & SMPN 1 Kampar & $7.524^{*}$ & 1.815 & .000 \\
\hline SMPN 1 Kampar & SMPN 1 Bangkinang & $-10.719 *$ & 1.665 & .000 \\
\hline
\end{tabular}

* The mean difference is significant at the 0.05 level.

\section{Discussion}

In this global era, teaching and learning process in today's classroom needs improving and keeps on changing from time to time based on the new situations and conditions. The educational needs keep on changing from Elementary school up to tertiary levels. Educators in general need to explore and search suitable approaches, methods, techniques and strategies to overcome the changing of the educational needs in their teaching and learning processes. The findings of this study highlight the idea that the scientific approach through ICT on the integration of the thrength of attitude, skill and knowledge could be successful to implement in Junior High School level in Riau Province, Indonesia. Based on the data analysis, the findings (Table 4 - Table 9) showed that there were significant effects of the scientific approach through ICT towards the students' English achievement at Junior High school level. Based on the findings, it could make an inference that the scientific approach through ICT could be implemented to any Junior High school levels in Indonesia. A similar study conducted by M. Zaim [15] aimed at investigating the implementation of scientific approach to teach English at Senior High School in Indonesia and problems of teaching and learning. The study used a descriptive research which focused on investigating five steps of communicative approach implemented by teachers in teaching and learning process. The data collection used observation and interview with the teachers and students in two senior high schools in Padang, Indonesia. The findings of related study showed that, among the five steps of scientific approach, the teachers were not able to implement the observing and questioning steps optimally, meanwhile, this study was a quasi-experimental research with pretest and post-test non-equivalent group design in three junior high schools in Riau province. This study investigated teaching and learning process as a whole starting from pre-activities, whilst-activities and post-activities of scientific approach through ICT and used both descriptive and inferential statistics with SPSS. The finding showed that there were significant effects of scientific approach on students' English achievement. In short, it can make an inference that communicative approach through ICT is suitable to implement in Junior High School level in Indonesia.

\section{Conclusion}

The findings indicated that the scientific approach through Information Communication Technology (ICT) in teaching English showed the significant effect on the students' English achievement. The implementation of the scientific approach through ICT should be integrated with the thrength of attitude, skill and knowledge; and teaching and learning process focused on student centered instruction that make the students become more active, creative, effective and joyful learning. Among three school categories, one school showed significant difference from two other schools on the student English achievement. This is due to lack of facilities in this school and less creativity and efforts done by the teacher. The teachers should be alert and creative to prepare the materials or other facilities like multimedia of teaching aids. At last, it can be inferred that the research findings can be generalized and implemented to other junior high schools in Indonesia.

\section{References}

[1] Wark, M. 2001. Cyberpunk-Subc ultural of Mainstream: Reading and Writing about American Popular Culture. Upper Saddle River, NJ:Prentice-Hall. http://merr.utm.my/id/eprint/14037.

[2] Suwarsih, 2002. Developing Standard for EFL in Indonesia as Part of the EFL Teaching Reform, TEFLIN Journal, Vol. 3 (2) 147-153

[3] Guidelines, Curriculum 2013 the Ministry of Education and culture number $81 \mathrm{~A}$, (2013).

[4] Brumfit, Christopher J. and Keith Johnson, eds. 1983. The Communicative Approach to Language Teaching. Oxford University Press.

[5] Harmer, J. 2006. The Practice of Language Teaching. Pearson Education. Limited. www.longman,com

[6] Smaldino,Sharon E, Lowther D.L, \& Russel James D 2008. Instructional technology and media for learning. Pearson Prentice Hall.

[7] Brown, H.Douglas. 2001. Principles of Language Learning and Teaching: Longman.

[8] Cohen, A.D. 1998. Strategies in Learning and Using as Second Language. New York: Addison Wesley Longman.

[9] Hatch, E.,\& Farhady, H. 1982. Research Methods and Statistics for Applied Linguistics, Rowley, MA: Newbury House.

[10] Bryman, A. 2001. Social Research Methods. Oxford: Oxford University Press.

[11] Pelham, B. W., \& Blanton, H. 2007. Conducting Research in Psychology: Measuring the Weight of Smoke, $3^{\text {rd }}$ ed. Belmont, CA: Thompson Learning/Wadsworth. 
[12] Chong Poh Wan, 2003. Effects of Cooperative Learning on Critical Thinking Skills and English Language Efficacy Beliefs on Pre-service TESl Teachers Ph.D thesis Universiti Kebangsaan Malaysia.

[13] Gay, L. R., \& Airisian, P. 2003.Educational Research Competencies for Analysis and Application. $7^{\text {th }}$ ed. New Jersey: Prentice hall.
[14] Pallant, J. 2001. SPSS Survival Manual. A step-by-step Guide to Data Analysis Using SPSS for Windows. New South Wales, Australia: Allen \& Unwin.

[15] M. Zaim, (2017). Implementing Scientific Approach to Teach English at Senior High School in Indonesia. Asean Social Science, Vol 13 (2) 33-40. 